\title{
POST-EXERCISE PROTEINURIA IN THE CADETS TRAINED ON SPECIAL AERIAL GYMNASTICS INSTRUMENTS
}

\section{ZBIGNIEW WOCHYŃSKI ${ }^{1}$ and KRZYSZTOF SOBIECH ${ }^{2}$}

\author{
${ }^{1}$ Polish Air Force Academy, Dęblin, Poland \\ Department of Physical Education \\ ${ }^{2}$ University School of Physical Education, Wrocław, Poland \\ Department of Human Biology
}

\begin{abstract}
Objectives: Assessment of the effect of training on Special Aerial Gymnastics Instruments (SAGI) on the urine $\beta$-2microglobulin ( $\beta$-2M), albumin (ALB), total protein (TP), N-acetyl- $\beta$-D-glucosaminidase EC.3.2.1.30 (NAG), expressed as creatinine $(\mathrm{Cr})$ and on the physical fitness of the examined cadets in comparison with the control group. Material and Methods: The study involved 55 cadets aged 20, divided into group A $(\mathrm{N}=41)$ trained on SAGI, and group B $(\mathrm{N}=14)$ a control group. The urine was collected twice: before the training (BT) and after the training (AT) at the start (training I), during (training II), and after completion of the training program (training III). Urine proteins were assayed with commercially available kits. Results: In group A, results obtained in trainings I, II and III showed a statistically significant increase in $\beta-2 \mathrm{M} / \mathrm{Cr}, \mathrm{NAG} / \mathrm{Cr}, \mathrm{TP} / \mathrm{Cr}, \mathrm{ALB} / \mathrm{Cr}$ indices in AT compared with the baseline BT values. Similarly in group B, a statistically significant increase in $\beta-2 \mathrm{M} / \mathrm{Cr}$, NAG/Cr (trainings I, II), TP/Cr, AT compared with the baseline BT values in trainings I, II, and III was noted. Comparison of both groups showed a higher value of the post-exercise proteinuria in group B than in group A. In group A, a significant correlation between $\mathrm{TP} / \mathrm{Cr}$ vs. $\mathrm{ALB} / \mathrm{Cr}, \mathrm{NAG} / \mathrm{Cr}$ vs. TP/Cr, $\beta-2 \mathrm{M} / \mathrm{Cr}$ vs. TP/Cr, i.e., $r=0.62$ at $p<0.001 ; r=0.33$ at $p=0.03 ; r=0.60$ at $p<0.001$, and $r=0.52$ at $p<0.001$, respectively, was observed in group A, training III, AT. Conclusions: Assayed urine proteins depend on the intensity of physical exercise, the type of exercise, and the level of physical fitness.
\end{abstract}

Key words:

Proteinuria, N-acetyl-p-D-glucosaminidase, $\beta$-2-microglobulin, Albumin, Creatinine, Special Aerial Gymnastics Instruments

\section{INTRODUCTION}

Training using Special Aerial Gymnastics Instruments (SAGI) is used to improve hand-eye coordination and spatial orientation [1]. Special Aerial Gymnastics Instruments contain the following instruments: a looping, a gyroscope, and an aero wheel. Exercises on SAGI belong to isometric exercises, which may produce proteinuria. Kidneys play a key role in the development of the post-exercise proteinuria [2]. An increase in the proteinuria during an intense physical exercise is caused by penetration of the plasma proteins into renal tubules [3]. Proteins, present in the urine after an exercise on SAGI may provide valuable information about the process of adaptation to the physical exercise. Proteinuria develops immediately after a physical exercise and may be observed for $24 \mathrm{~h}$ thereafter [4]. An increase in proteinuria depends

This work was funded by the grants for 2009-2010 as a developmental project (No. O R/00 001706). Grant manager: Marek Grzegorzewski, Ph.D.

Received: September 7, 2014. Accepted: January 24, 2015.

Corresponding author: Z. Wochyński, Polish Air Force Academy, Department of Physical Education, Dywizjonu 303, 08-521 Dęblin, Poland (e-mail: zbigniew.wochynski@op.pl). 
on the degree of the human body adaptation to the physical load in both aerobic and anaerobic metabolism. Higher proteinuria was found in the case of anaerobic metabolism, compared with aerobic metabolism [5]. It has been also seen that people who are less physically active have a higher level of this protein in urine. Post-exercise proteinuria has been found in various sport disciplines but the highest level has been noticed after swimming training $[6,7]$. Proteinuria depends on the type of exercise and its intensity $[3,8,9]$.

Among several proteins existing in urine, measured after the training, albumin was notably on the highest level. This phenomenon was called post-exercise albuminuria $[6,10]$. $\beta$-2Microglobulin ( $\beta-2 \mathrm{M})$, albumin (ALB), total protein (TP), and N-acetyl- $\beta$-D-glucosaminidase EC.3.2.1.30 (NAG), expressed as creatinine $(\mathrm{Cr})$, were used as exercise markers because of their high diagnostic role. N-acetyl- $\beta$-Dglucosaminidase EC.3.2.1.30 is a lisosomal enzyme catalyzing splitting $\mathrm{N}$-acetyl- $\beta$-D-glucosaminidase or $\mathrm{N}$-acetylgalactosamines off various oligosaccharides in glycopeptides and glycoproteids. Its activity has been shown in both tissues [11] and body fluids [12] in a form of A and B isoenzymes. Under physiological conditions, NAG activity in urine is rather low, as it does not filter through healthy renal corpuscles. An increase in its activity may reflect structural changes in kidneys with particular reference to renal tubules. $\beta$-2-Microglobulin is a protein of molecular weight $11.8 \mathrm{kDa}$, which increases after an exercise. It consists of 100 amino acids and practically does not contain carbohydrates.

An increase in $\beta-2 \mathrm{M}$ levels in urine indicates damage of proximal renal tubules in normal renal glomeruluses functioning. $\beta$-2-microglobulin undergoes a glomerular filtration, being initially bound to brush border of the proximal tubules cells and then, absorbed by micropinocytosis. It is degraded in the lysosomes of the renal tubule cells. An increase in $\beta-2 \mathrm{M}$, associated with NAG, may illustrate changes in the kidneys [13].
There are no reports on the post-exercise proteinuria after training on SAGI. We attempted to evaluate a diagnostic value of the above listed proteins to monitor physical load of the cadets trained on SAGI in comparison with a control group, in which the character and intensity of physical exercises differentiated. A key issue we examined is whether SAGI exercises of low level intensity might make one's body heavier than another form of high level intensity exercises. The answer to the question is of tremendous importance in the training process. At the same time, the cadets' general physical fitness was assessed as an effect of the use of specific exercises on SAGI.

During the course of the research, a following hypothesis has been formulated - with the use of the applied exercise markers: NAG/Cr. $\beta$-2-microglobulin/creatinine, $\mathrm{ALB} / \mathrm{Cr}$ and $\mathrm{TP} / \mathrm{Cr}$, it will be possible to determine the level of exercise adaptation, the type of proteinuria depending on the character (type) and the intensity of physical effort among people exercising with SAGI in comparison with the control group.

\section{MATERIAL AND METHODS}

\section{Subjects}

The study involved 55 cadets (men), aged 20 years, divided into 2 groups: group $\mathrm{A}(\mathrm{N}=41)$, trained on SAGI, and group $B(\mathrm{~N}=14)$, which served as a control group. The groups used a standard program of physical education. In both groups, urine samples were collected twice before the training (BT) and after the training (AT) at the beginning (training I), during (training II), and after (training III) completion of the training program with the use of SAGI. The urine samples were collected BT, in each training at 9:00 a.m. and AT at 11:00 a.m. In both groups the physical education program consisted of 20 training units. The whole education program lasted 70 days. Each training was 90 min long.

The authors obtained a permission from the appropriate ethical commission to perform the study. Consent of 
the proper bioethical commission for the research studies was obtained (decision No. 03A/2009 of 08.07.2009 of the Ethical Commission on Biomedical Research Studies at the Military Institute of Aviation Medicine, Warszawa, Poland). The study was conducted according to the ethical standards of the International Journal of Sports Medicine [14], and was approved by the local ethics committee.

\section{Measurements}

Urine ALB, TP, NAG, $\beta$-2M, and $\mathrm{Cr}$ were assayed with the following techniques:

- albumin with the immunoturbidimetric technique, using ROCHE reagents and Cobas Integra 400/800 Analyzer;

- TP was assayed with pyrogallol red, using ROCHE reagents and Integra 400/800;

- urine NAG was assayed with the colometric technique [15], using Sigma Aldrich (USA) reagents, measuring concentration of the released p-nitrophenyl-2acetamide-2-desoxy- $\beta$-2-glucopiranoside; results were read with Perkin Elmer, USA spectrometer;

- $\beta$-2M was assayed with the chemiluminescence technique using IMMULITE 1000 device (SIEMENS);

- Cr was assayed with the Jaffee technique, using ROCHE reagents and Integra 400/800.

Training intensity was monitored in both groups using Polar Team-2 Pro, which recorded the heart rate (HR). The procedure consisted of a belt with HR recorder fitted at the chest level, recording HR during the whole training. Then, the HR recorder was detached and put into a device reading changes in $\mathrm{HR}$.

\section{Procedure and design}

Training program

In group $\mathrm{A}$, the level of intensity in all the 3 trainings was similar. The training was performed with intervals between all the trainings. The training consisted of a sequence of the following exercises:
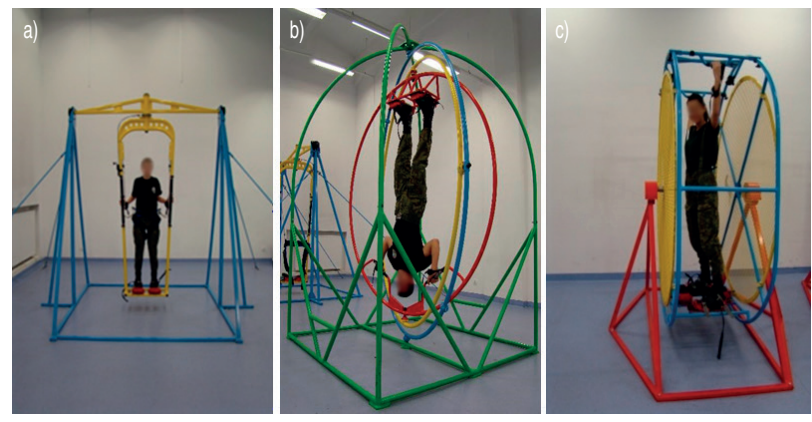

Photo 1. Special Aviation Gymnastics Instruments:

a) a looping, b) a gyroscope, c) an aero wheel

- Looping - 2 series of turns on the blocked looping. Each series consisted of 10 turns forwards and 10 turns backwards (Photo 1a). Interval between the series of turns was $20 \mathrm{~s}$. The pause before the next exercise on a gyroscope was $3 \mathrm{~min}$.

- Gyroscope - 2 series of dynamic turns with rotations on a gyroscope, each lasting $60 \mathrm{~s}$. Interval between the series was $20 \mathrm{~s}$ (Photo $1 \mathrm{~b}$ ). The pause before the next exercise on an aero wheel was 3 min.

- Aero wheel - 2 series of turns. Each series consisted of 3 turns sideways to the right and 3 turns sideways to the left. Each series was repeated 4 times, alternatively 3 turns in each direction (Photo 1c). Interval between the series was $20 \mathrm{~s}$. The pause before the next exercise on an unplugged looping was $3 \mathrm{~min}$.

\section{Standard program of physical education}

In group $\mathrm{B}$, exercises of similar intensity were performed in all the 3 trainings. The physical education program included exercises improving general physical fitness with an emphasis on all motor capabilities. Standard team sports, light athletics, gymnastics, outdoors runs. Intensity of all exercises was quite high to increase body functional abilities and to adapt to a higher load in the further stage of education. The so-called goal technique, repetitions, and interval techniques were used during the training. In both groups, apart from different training programmes, 
the same all-day physical activity including drilling, marching, and other military activities in the period of the experiment have been additionally performed.

The cadets' fitness was assessed before (series I) and after (series II) completion of the study on proteinuria, using fitness tests, such as: the Aero-Synthetic Efficiency Test (ASET) [16], shuttle race $10 \times 10 \mathrm{~m}$, pulling-up on a bar, sprint for $16.5 \mathrm{~m}$, and body bending forward.

All the examined cadets were provided with the same board and lodging. They consumed a standard diet complying with the standards of nutrition. Daily food rations contained $4500 \mathrm{kcal}$, including $150 \mathrm{~g}$ of fat $(30 \%), 112.5 \mathrm{~g}$ of protein $(10 \%)$, and $675 \mathrm{~g}$ of carbohydrates $(60 \%)$.

The cadets in both groups drank water before and after the training, about 11 in total. They were doing exercises while the surrounding temperature was $18^{\circ} \mathrm{C}$.

\section{Statistical analysis}

In the statistical research, the average and standard deviations of all the indices were calculated. Normal distribution of variables was verified by means of the Kolmogorov-Smirnov test. The assumption concerning homogeneity of variances was verified by means of the Levene's test. The difference between the indices before and after the training in both groups was calculated by means of the Benferroni test. Comparison of the indices before and after the training between both groups was performed using the variance analysis (ANOVA). The correlation r-Pearson between the indices in the researched groups was calculated. Statistical analysis of the research findings was performed by means of the statistical software Statistica 9. The differences between the average values were considered to be vital when the calculated $\mathrm{p}<0.05$.

\section{RESULTS}

The obtained results showed a statistically insignificant difference between the examined groups in such parameters as: age, height, body weight, and body mass index (BMI) (Table 1).

In group $\mathrm{A}$, the assays of the examined markers showed a statistically significant increase in $\mathrm{ALB} / \mathrm{Cr}, \mathrm{TP} / \mathrm{Cr}$, and $\beta-2 \mathrm{M} / \mathrm{Cr}$ AT in all the 3 trainings at $\mathrm{p}<0.001$ in comparison with the BT values (Table 2). N-acetyl- $\beta$-Dglucosaminidase EC.3.2.1.30/creatinine increased insignificantly AT in trainings I, II, and III at $p<0.005$, $\mathrm{p}<0.001$, and $\mathrm{p}<0.05$, respectively in comparison with the BT values (Table 2).

Table 1. Demographic data and the heart rate in the studied groups [36]

\begin{tabular}{lrrr}
\hline & \multicolumn{1}{c}{$\begin{array}{c}\text { Group A } \\
(\mathrm{N}=41) \\
(\mathrm{M} \pm \mathrm{SD})\end{array}$} & $\begin{array}{r}\text { Group B } \\
(\mathrm{N}=14) \\
(\mathrm{M} \pm \mathrm{SD})\end{array}$ & $\mathrm{p}$ \\
\hline Age [years] & $20.53 \pm 1.02$ & $20.21 \pm 0.42$ & n.s. \\
Height $[\mathrm{cm}]$ & $176.64 \pm 5.78$ & $173.62 \pm 5.12$ & n.s. \\
Body weight $[\mathrm{kg}]$ & $71.03 \pm 6.94$ & $67.59 \pm 6.36$ & n.s. \\
BMI $\left[\mathrm{kg} / \mathrm{m}^{2}\right]$ & $22.82 \pm 1.95$ & $22.49 \pm 1.87$ & n.s. \\
HR [bpm] from the training unit & & & \\
$\quad$ training I & $108.5 \pm 11.80$ & $131.6 \pm 15.80$ & $<0.001$ \\
$\quad$ training II & $107.3 \pm 11.70$ & $139.7 \pm 8.80$ & $<0.001$ \\
training III & $101.7 \pm 7.69$ & $145.3 \pm 6.70$ & $<0.001$ \\
\hline
\end{tabular}

BMI - body mass index; HR - heart rate; M - mean; SD - standard deviation; n.s. - statistically non-significant. 
Table 2. Changes in proteinuria before and after the training on Special Aerial Gymnastics Instruments in group A $(\mathrm{N}=41)$ in trainings I, II, and III

\begin{tabular}{|c|c|c|c|c|c|c|c|c|c|}
\hline \multirow[b]{2}{*}{ Ratio } & \multicolumn{3}{|c|}{ Training I } & \multicolumn{3}{|c|}{ Training II } & \multicolumn{3}{|c|}{ Training III } \\
\hline & $\begin{array}{c}\mathrm{BT} \\
(\mathrm{M} \pm \mathrm{SD}) \\
\end{array}$ & $\begin{array}{c}\mathrm{AT} \\
(\mathrm{M} \pm \mathrm{SD})\end{array}$ & $\mathrm{p}$ & $\begin{array}{c}\mathrm{BT} \\
(\mathrm{M} \pm \mathrm{SD})\end{array}$ & $\begin{array}{c}\mathrm{AT} \\
(\mathrm{M} \pm \mathrm{SD})\end{array}$ & $\mathrm{p}$ & $\begin{array}{c}\mathrm{BT} \\
(\mathrm{M} \pm \mathrm{SD})\end{array}$ & $\begin{array}{c}\mathrm{AT} \\
(\mathrm{M} \pm \mathrm{SD})\end{array}$ & $\mathrm{p}$ \\
\hline $\mathrm{ALB} / \mathrm{Cr}[\mathrm{mg} / \mathrm{g}]$ & $5.57 \pm 4.27$ & $24.12 \pm 16.82$ & $<0.001$ & $5.50 \pm 4.14$ & $19.79 \pm 17.87$ & $<0.001$ & $4.50 \pm 2.90$ & $26.70 \pm 17.85$ & $<0.001$ \\
\hline $\mathrm{TP} / \mathrm{Cr}[\mathrm{mg} / \mathrm{g}]$ & $6.59 \pm 4.01$ & $8.73 \pm 4.59$ & $<0.001$ & $6.76 \pm 2.30$ & $10.95 \pm 4.62$ & $<0.001$ & $5.94 \pm 1.72$ & $9.58 \pm 6.13$ & $<0.001$ \\
\hline $\mathrm{NAG} / \mathrm{Cr}[\mathrm{U} / \mathrm{g}]$ & $1.66 \pm 0.49$ & $1.89 \pm 0.53$ & $<0.005$ & $1.52 \pm 0.36$ & $1.84 \pm 0.39$ & $<0.001$ & $1.46 \pm 0.60$ & $1.62 \pm 0.41$ & $<0.050$ \\
\hline$\beta-2 \mathrm{M} / \mathrm{Cr}[\mathrm{mg} / \mathrm{g}]$ & $0.07 \pm 0.02$ & $0.09 \pm 0.05$ & $<0.001$ & $0.06 \pm 0.02$ & $0.09 \pm 0.04$ & $<0.001$ & $0.06 \pm 0.02$ & $0.11 \pm 0.05$ & $<0.001$ \\
\hline
\end{tabular}

$\mathrm{ALB} / \mathrm{Cr}$ - albumin/creatinine; TP/Cr - total protein/creatinine; $\mathrm{NAG} / \mathrm{Cr}$ - N-acetyl- $\beta$-D-glucosaminidase/creatinine; $\beta$-2M/Cr - $\beta$-2-microglobulin/ creatinine.

BT - before the training; AT - after the training.

Other abbreviations as in Table 1.

In group B, a statistically significant increase in $\mathrm{ALB} / \mathrm{Cr}$ in training $\mathrm{I}(\mathrm{p}<0.005)$ AT was noted in comparison with the BT values (Table 3). A significant increase in $\mathrm{TP} / \mathrm{Cr}$ was found AT in all the 3 trainings $p<0.05, p<0.005$, and $\mathrm{p}<0.001$, respectively in comparison with the BT values. An increase in NAG/Cr AT in training I was insignificant, whereas it was significant in trainings II and III at $p<0.001$ and $p<0.005$ in comparison with the BT values. After the training, a significant increase in $\beta-2 \mathrm{M} / \mathrm{Cr}$ was seen in all the 3 trainings at $p<0.001, p<0.005$, and $p<0.001$, respectively (Table 3 ).

Before the training and after it, the value of ALB/ Cr was significantly higher in group B in training II at $\mathrm{p}<0.001$ (Table 3 ). Both before and after the training, a decrease in NAG/Cr value was statistically insignificant in group B in comparison with group A. After the training, statistically significant higher $\mathrm{TP} / \mathrm{Cr}$ values were noted in group B than those in group A in all the 3 trainings at $p<0.001, p<0.005$, and $p<0.001$, respectively (Table 3 ). After the training, an increase in $\beta-2 \mathrm{M} / \mathrm{Cr}$ value in group $\mathrm{B}$ was statistically significant in trainings I and II at $p<0.01$ and $p<0.001$, respectively.

In group A, AT correlation between $\mathrm{TP} / \mathrm{Cr}$ and $\mathrm{ALB} / \mathrm{Cr}$ was significant in all the 3 trainings, i.e., $r=0.54$ at $\mathrm{p}<0.001, \mathrm{r}=0.37$ at $\mathrm{p}=0.01$, and $\mathrm{r}=0.62$

Table 3. Changes in proteinuria before and after the training on Special Aerial Gymnastics Instruments in group B ( $=14)$ in trainings I, II and III

\begin{tabular}{|c|c|c|c|c|c|c|c|c|c|}
\hline \multirow[b]{2}{*}{ Ratio } & \multicolumn{3}{|c|}{ Training I } & \multicolumn{3}{|c|}{ Training II } & \multicolumn{3}{|c|}{ Training III } \\
\hline & $\begin{array}{c}\mathrm{BT} \\
(\mathrm{M} \pm \mathrm{SD})\end{array}$ & $\begin{array}{c}\mathrm{AT} \\
(\mathrm{M} \pm \mathrm{SD})\end{array}$ & $\mathrm{p}$ & $\begin{array}{c}\mathrm{BT} \\
(\mathrm{M} \pm \mathrm{SD})\end{array}$ & $\begin{array}{c}\mathrm{AT} \\
(\mathrm{M} \pm \mathrm{SD})\end{array}$ & $\mathrm{p}$ & $\begin{array}{c}\mathrm{BT} \\
(\mathrm{M} \pm \mathrm{SD})\end{array}$ & $\begin{array}{c}\mathrm{AT} \\
(\mathrm{M} \pm \mathrm{SD})\end{array}$ & $\mathrm{p}$ \\
\hline $\mathrm{ALB} / \mathrm{Cr}[\mathrm{mg} / \mathrm{g}]$ & $6.33 \pm 5.36$ & $33.02 \pm 28.49$ & $<0.005$ & $4.11 \pm 1.50$ & $49.35^{\mathrm{c}} \pm 22.59$ & $<0.001$ & $4.73 \pm 2.92$ & $25.71 \pm 11.63$ & $<0.001$ \\
\hline $\mathrm{TP} / \mathrm{Cr}[\mathrm{mg} / \mathrm{g}]$ & $7.54 \pm 3.77$ & $11.91 \pm 7.91$ & $<0.050$ & $7.85 \pm 3.11$ & $15.34^{\mathrm{a}} \pm 6.24$ & $<0.005$ & $6.80 \pm 1.79$ & $18.21^{c} \pm 9.03$ & $<0.001$ \\
\hline $\mathrm{NAG} / \mathrm{Cr}[\mathrm{U} / \mathrm{g}]$ & $2.44^{c} \pm 0.49$ & $2.50^{c} \pm 0.34$ & n.s. & $1.51 \pm 0.31$ & $2.43^{b} \pm 0.93$ & $<0.001$ & $1.53 \pm 0.31$ & $2.27^{c} \pm 0.65$ & $<0.005$ \\
\hline$\beta-2 \mathrm{M} / \mathrm{Cr}[\mathrm{mg} / \mathrm{g}]$ & $0.07 \pm 0.02$ & $0.14^{\mathrm{a}} \pm 0.05$ & $<0.001$ & $0.07 \pm 0.03$ & $0.21^{\mathrm{c}} \pm 0.13$ & $<0.005$ & $0.05 \pm 0.02$ & $0.08 \pm 0.02$ & $<0.010$ \\
\hline
\end{tabular}

Abbreviations as in Tables 1 and 2.

Difference statistically significant in comparison with group A at: ${ }^{\mathrm{a}} \mathrm{p}<0.01,{ }^{\mathrm{b}} \mathrm{p}<0.005,{ }^{\mathrm{c}} \mathrm{p}<0.001$. 
Table 4. Correlations between the analyzed ratios in the 3 trainings in groups A and B after the training

\begin{tabular}{lcccccc}
\hline \multirow{2}{*}{ Correlations } & \multicolumn{3}{c}{ Group A } & \multicolumn{3}{c}{ Group B } \\
\cline { 2 - 7 } & training I & training II & training III & training I & training II & training III \\
\hline $\mathrm{TP} / \mathrm{Cr}$ vs. ALB/Cr & $0.54^{\mathrm{c}}$ & $0.37^{\mathrm{b}}$ & $0.62^{\mathrm{c}}$ & $0.91^{\mathrm{c}}$ & 0.27 & 0.09 \\
$\mathrm{NAG} / \mathrm{Cr}$ vs. TP/Cr & 0.15 & -0.09 & $0.33^{\mathrm{a}}$ & -0.40 & 0.05 & 0.02 \\
$\beta-2 \mathrm{M} / \mathrm{Cr}$ vs. NAG/Cr & 0.15 & 0.08 & 0.18 & 0.02 & -0.29 & -0.04 \\
$\beta-2 \mathrm{M} / \mathrm{Cr}$ vs. ALB/Cr & 0.09 & -0.06 & $0.60^{\mathrm{c}}$ & -0.33 & 0.18 & -0.18 \\
$\mathrm{ALB} / \mathrm{Cr}$ vs. NAG/Cr & 0.12 & -0.01 & 0.15 & -0.38 & -0.16 & 0.40 \\
$\beta-2 \mathrm{M} / \mathrm{Cr}$ vs. TP/Cr & $0.60^{\mathrm{c}}$ & 0.15 & $0.52^{\mathrm{c}}$ & -0.34 & -0.04 & -0.42 \\
\hline
\end{tabular}

Abbreviations as in Tables 1 and 2.

Level of significance: ${ }^{\mathrm{a}} \mathrm{p}=0.03 ;{ }^{\mathrm{b}} \mathrm{p}=0.01 ;{ }^{\mathrm{c}} \mathrm{p}<0.001$.

at $\mathrm{p}<0.001$, respectively. It was also found that the correlation between $\mathrm{NAG} / \mathrm{Cr}$ vs. $\mathrm{TP} / \mathrm{Cr}$, and $\beta-2 \mathrm{M} / \mathrm{Cr}$ vs. $\mathrm{ALB} /$ Cr was significant AT in training III: $r=0.33$ at $p=0.03$ and $r=0.60$ at $p<0.001$, respectively. After the training the correlation between $\beta-2 \mathrm{M} / \mathrm{Cr}$ vs. $\mathrm{TP} / \mathrm{Cr}$ was significant in trainings I and III: $r=0.6$ and $r=0.52$ at $p<0.001$. In group $\mathrm{A}$, a statistically insignificant correlation between $\beta-2 \mathrm{M} / \mathrm{Cr}$ vs. $\mathrm{NAG} / \mathrm{Cr}$ and $\mathrm{ALB} / \mathrm{Cr}$ vs. $\mathrm{NAG} / \mathrm{Cr}$ was found (Table 4).

In group $\mathrm{B}$, a strong positive correlation between $\mathrm{TP} / \mathrm{Cr}$ and $\mathrm{ALB} / \mathrm{Cr}$ was found AT in training $\mathrm{I}: \mathrm{r}=0.91$ at $p<0.001$. No significant correlation of the remaining parameters was seen in all the 3 trainings (Table 4). However, correlations in group A and group B are interesting in training III.

Assessment of physical fitness in group A showed a statistically significant improvement in series II in pulling up on a bar ( $\mathrm{p}<0.01)$, race for $16.5 \mathrm{~m}(\mathrm{p}<0.001)$, body bending forward $(\mathrm{p}<0.001)$ and ASET $(\mathrm{p}<0.001)$, comparing with series I (Figure 1).

In group B, a statistically significant improvement in physical fitness related to the pulling up on a bar $(p<0.005)$, body bending forward $(p<0.001)$, and ASET $(p<0.05)$ in comparison with series I. An improvement in the result of race for $16.5 \mathrm{~m}$ proved to be statistically insignificant (Figure 1).
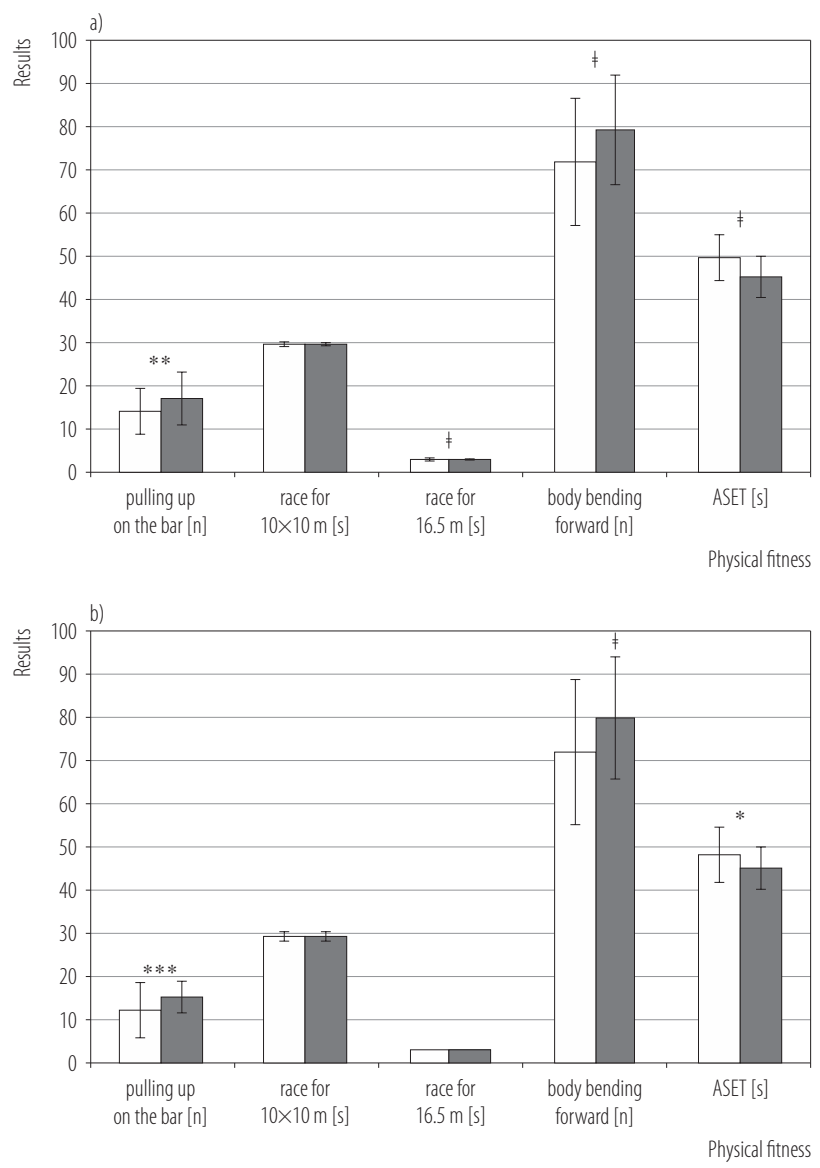

ASET - Aero-Synthetic Efficiency Test.

Different statistical significance in comparison with series I at: ${ }^{*} \mathrm{p}<0.05 ;{ }^{* *} \mathrm{p}<0.01 ; * * * \mathrm{p}<0.005 ; \neq \mathrm{p}<0.001$.

Fig. 1. Changes of physical fitness in a) group A and b) group B before (series I) and after (series II) completion of the education cycle [36] 
In both groups an improvement of the results of a shuttle race for $10 \times 10 \mathrm{~m}$ was insignificant in series II in comparison with series I (Figure 1).

\section{DISCUSSION}

The investigated groups differ in the intensity and type of exercises performed during the training. The results obtained in both groups showed an increase in $\mathrm{TP} / \mathrm{Cr}$, $\mathrm{NAG} / \mathrm{Cr}, \beta-2 \mathrm{M} / \mathrm{Cr}$, and $\mathrm{ALB} / \mathrm{Cr}$ after the exercise in all the 3 trainings, which is confirmed by the recorded HR (Table 1). Lower values of these parameters in group A than those in group B indicate a lower intensity of exercises, longer intervals between changing instruments, and exercise specificity. In group A, the values of the urine $\mathrm{ALB} / \mathrm{Cr}$ AT indicate microalbuminuria (> $25 \mathrm{mg} / \mathrm{g}$ ) only in training III. In group B, higher values of microalbuminuria were seen AT in all the 3 trainings. The level of microalbuminuria depends on the glomerular filtration barrier functioning [5,17]. It was found that a regular physical exercise is associated with a lower ALB/Cr rate in the BT values in all the 3 trainings. It is a reaction similar to this observed in the triathlonists; their urine $\mathrm{ALB} / \mathrm{Cr}$ and $\mathrm{TP} / \mathrm{Cr}$ ratios initially increased and gradually decreased parallel to the continuous physical effort.

It indicated a decrease in GFR [18]. Other authors have found that the intermittent exercise on a cycle ergometer exerted a higher effect on the higher excretion of both albumin and total protein into the urine than the continuous exercise. This fact has been associated with changes of the urine $\mathrm{pH}$ [19]. Lower values of the urine $\mathrm{TP} / \mathrm{Cr}$ found before and after the exercise in group $\mathrm{A}$ in comparison with group B indicate that the type of exercise together with its intensity play an important role. In group A, the examined cadets performed isometric exercises with simultaneous body ration in various planes during the training on SAGI. Despite its lower intensity, this training could increase a higher demand for proteins. This is particularly seen at BT in training III in comparison with group B. It could be confirmed by the physical fitness tests performed in both groups at the end of the education program. In group A, the examined cadets performed isometric exercises accompanied by body rotations in different planes on SAGI.

These exercises (despite their lower intensity) could increase a body demand for the proteins. It was particularly visible in the BT values in training III in comparison with group B. Such a hypothesis was confirmed by the fitness tests performed in both groups at the end of the trainings. In group $\mathrm{A}$, the results of some fitness tests were better (Figure 1). Similar conclusions have been drawn [20] when measuring grip strength and leg strength in the subjects with and without proteinuria. Those authors have found that the leg strength per kg body weight was lower in men with proteinuria than that in men without proteinuria, after adjusting for age. Grip strength was also lower but not significantly. Evaluation of proteinuria AT under an increased demand for oxygen is also important. Our results showed a higher demand in group B than that in group A, especially in trainings II and III (Table 3). A 30-time increase in $\mathrm{TP} / \mathrm{Cr}$ in the light athletes was noted after interval training in anaerobic-lactate metabolism and a return to the values similar to those BT after $24 \mathrm{~h}[4,21]$. In the marathon runners [22] and triathlonists [13], similar effects have been also observed. It is known that the return of the proteins to the normal values is more rapid in the individuals who are used to physical effort.

Exercise-produced protein catabolism may result from the disturbed body energy balance leading to both proteinuria and an increase in the lactic acid level. In such a case, anabolic processes are decelerated. Sós [23] studies may explain it; the author has shown a reduction of the elevated plasma lactate level in the swimmers trained with maximum intensity in 3 macrocycles (970 km per week for 6 weeks).

He used a special diet supplementation notably reducing the plasma lactate level and proteinuria despite 
maintaining the same training load. Sós [23] suggests that the diet supports a mechanism responsible for lactate elimination and reduction of the protein catabolism and/or protein reabsorption. In our study, we did not assay proteinuria after $24 \mathrm{~h}$ as the cadets were not physically loaded as professional athletes are. Therefore, the AT values are comparable with the baseline values and not with the ones indicating not reduced symptoms of the fatigue. A decreasing tendency of $\mathrm{TP} / \mathrm{Cr}$ values may be seen from the baseline values in all the 3 series of assays. It may be explained by the increased protein biosynthesis also indicating adaptation to physical effort.

Comparison of $\mathrm{TP} / \mathrm{Cr}$ values in both groups suggests that proteinuria in our study depended on the exercise intensity and not on its duration. It is confirmed by the study of Bellinghieri et al. [24]. Those authors have found that proteinuria depends on the type of an exercise and its intensity and not on its duration. Correlation $r=0.85$ between venous lactate and ALB and TP following runs of the maximum intensity, for various distances, shown by Portmans and Labilloy [5], indicates that the exercise intensity and not its duration exerts an effect of proteinuria and albuminuria (microalbuminuria). N-acetyl- $\beta$-D-glucosaminidase EC.3.2.1.30 is considered a good marker of renal tubules damage [25]. In this study, an increase in the NAG/Cr value was found in both groups after the exercise. However, group $\mathrm{B}$ was characterized by higher values of this ratio in comparison with group $\mathrm{A}$. $\mathrm{N}$-acetyl$\beta$-D-glucosaminidase EC.3.2.1.30/creatinine ratio indicated a higher body overload in group B than the one in group A AT. Decreasing tendency of this ratio both before and after the exercise in both groups, especially in trainings II and III, may mean that the body adapts to the used load. Nowacka et al. [26] have found an increase in $\mathrm{NAG} / \mathrm{Cr}$ values in light athletes training under anaerobiclactate conditions.

Parallel to the training, a decrease in NAG/Cr value was seen in the subsequent microcycles. It was considered as a body adaptation to the exercise. It is not known why no significant increase in $\mathrm{NAG} / \mathrm{Cr}$ value was seen in group B AT in comparison with its BT value. In other studies [27], no significant increase in $\mathrm{NAG} / \mathrm{Cr}$ value has been found after the exercise, similarly to our group B. Probably in group B, exercise did not increase susceptibility to the used load in training I. The value of $\beta-2 \mathrm{M} / \mathrm{Cr}$ increases statistically significantly during a more intensive physical exercise.

This was confirmed by the statistical analysis, which showed statistically significant higher values in $\beta-2 \mathrm{M} / \mathrm{Cr}$ in group $\mathrm{B}$ compared with group A in trainings I and II. An exerciseinduced increase in $\beta-2 \mathrm{M} / \mathrm{Cr}$ values may result from the reduced blood renal flow and an increase in serum oxygen free radicals. An increase in $\beta-2 \mathrm{M} / \mathrm{Cr}$ values may result from the damage of the glomerular filtration barrier. Under normal conditions, this barrier retains the majority of plasma proteins [28,29]. All podocyte layers with adjacent space [30], which are sensitive to the lesions [31], play a particular role in the glomerular filtration barrier. In both our groups, a decreasing tendency in BT $\beta-2 \mathrm{M} / \mathrm{Cr}$ ratio (training III) with the training duration was shown, suggesting kidneys adaptation to the physical exercise. The correlations between $\beta-2 \mathrm{M} / \mathrm{Cr}$, NAG/Cr, TP/Cr, and $\mathrm{ALB} / \mathrm{Cr}$ ratios provided important information. In group $\mathrm{B}$, a positive correlation between $\mathrm{ALB} / \mathrm{Cr}$ and $\mathrm{TP} / \mathrm{Cr}$, i.e., $\mathrm{r}=0.91$, was found in the value AT in training I.

This fact might be associated with a higher effort and no adaptation to the physical exercise. Lower correlation at the same intensity of the exercise was shown after the training in trainings II and III. It could be explained by a body adaptation. A different situation took place in group $\mathrm{A}$, in which a statistically significant positive correlation between $\mathrm{ALB} / \mathrm{Cr}$ and $\mathrm{TP} / \mathrm{Cr}$ was noted in the $\mathrm{AT}$ values in all the 3 trainings. With continuation of the training, the examined cadets improved the technique of exercises and could increase their intensity, which is confirmed by the highest correlation between $\mathrm{ALB} / \mathrm{Cr}$ and $\mathrm{TP} / \mathrm{Cr}$ 
after the training in training III. Change of body position and the type of training on SAGI may result in an oxidative stress in the examined cadets. The published results of the study by Sentürk et al. [32] have indicated that physical exercise induces oxidative stress, which may lead to proteinuria in sedentary and trained men.

The higher level of free radicals, the higher proteinuria. Higher proteinuria in group B is probably induced by the decreased cellular redox potential. It has been demonstrated that physical exercise induces an urinary excretion of $\mathrm{ZnCu}$-superoxide dismutase [33]. Bovio et al. [34] have shown a correlation between urinary $\mathrm{Zn}$ excretion and serum $\mathrm{Zn}$ level. In group $\mathrm{A}$, a positive correlation between $\mathrm{NAG} / \mathrm{Cr}$ and $\beta-2 \mathrm{M} / \mathrm{Cr}(\mathrm{r}=0.18)$ was found in training III in comparison with group $\mathrm{B}$ despite the lower intensity of exercises. It was found that the glomerular proteinuria is started by light physical exercises, while heavy training produces mixed glomerular-tubular proteinuria [3]. In group A, the correlation between $\mathrm{NAG} / \mathrm{Cr}$ and $\beta-2 \mathrm{M} / \mathrm{Cr}$ ratios indicates mixed proteinuria. In training III, statistically significant correlations between $\mathrm{TP} / \mathrm{Cr}$ and $\beta-2 \mathrm{M} / \mathrm{Cr}$ and $\mathrm{NAG} / \mathrm{Cr}$ and $\mathrm{TP} / \mathrm{Cr}$ ratios were seen in group A. It could be associated with stress and renal load during specific exercises on SAGI. These exercises markedly load the body because of $+\mathrm{Gz}$ (head-legs direction) and -Gz (legs-head direction).

Exercises on SAGI are associated with a marked effect on the receptors in both the cardiovascular system and the CNS. They result in an elevation of blood pressure. Proteinuria may depend on the damage of the glomerular filtration barrier, which is highly selective size and shape structure for serum proteins. Structural and functional integrity of all its layers also plays an important role [17]. Podocytes with their receptors sensitive to the changes of blood pressure and contractile apparatus exerting a significant effect on GFR [27,29] constitute a key element of the filtration barrier. Exercises on SAGI may temporarily damage renal corpuscles and tubuli.
Renal hemodynamic changes associated with vessels walls permeability may cause glomerular proteinuria during an exercise [24]. In group B, a negative correlation between NAG/ $\mathrm{Cr}$ and $\beta-2 \mathrm{M} / \mathrm{Cr}(\mathrm{r}=-0.04)$ was noted. It may suggest that the damage of the glomeruli not always correlates with the damage of renal tubuli. It means that the type of exercise and body position also play an important role [35]. Yaguchi et al. [13] have shown a positive correlation $r=0.70$ at $p=0.006$ between $\mathrm{NAG} / \mathrm{Cr}$ and $\beta-2 \mathrm{M} / \mathrm{Cr}$ after a triathlon, consisting of $10 \mathrm{~km}$ run, $40 \mathrm{~km}$ cycling, and $1.5 \mathrm{~km}$ swimming. However, no significant correlation between $\mathrm{TP} / \mathrm{Cr}$ and $\beta-2 \mathrm{M} / \mathrm{Cr}(\mathrm{r}=-0.02)$ and $\mathrm{NAG} / \mathrm{Cr}$ and $\mathrm{TP} / \mathrm{Cr}(\mathrm{r}=0.01)$ was noted. In group $\mathrm{B}$, the correlation between $\mathrm{TP} / \mathrm{Cr}$ and $\beta-2 \mathrm{M} / \mathrm{Cr}(\mathrm{r}=-0.42)$ was negative, whereas the correlation between $\mathrm{NAG} / \mathrm{Cr}$ and $\mathrm{TP} / \mathrm{Cr}(\mathrm{r}=0.02)$ was positive, similarly to the effect of a triathlon [13].

Considering changes of BT and AT ratios in all the 3 trainings and comparing both groups, one should stress that higher proteinuria was noted in group B than in group A with a simultaneous higher intensity of the physical exercise. Correlations in group A indicate temporary impairment of the filtration barrier, i.e., impaired re-absorption tubular function. It is confirmed by the positive correlation between $\mathrm{NAG} / \mathrm{Cr}$ and $\beta-2 \mathrm{M} / \mathrm{Cr}$. In group $\mathrm{B}$, the negative correlation between $\mathrm{NAG} / \mathrm{Cr}$ and $\beta-2 \mathrm{M} / \mathrm{Cr}$ may suggest co-operation of these 2 mechanisms. Considering general physical fitness in both groups, it should be stressed that the training on SAGI exerts a comprehensive effect on the cadets' motor capabilities in group A. It is confirmed by the higher number of the competitions in series II in which a statistically significant improvement was achieved in comparison with series I and group B.

Summing up, the obtained results showed that that the values of $\mathrm{TP} / \mathrm{Cr}$ and $\mathrm{NAG} / \mathrm{Cr}$ ratios differentiate the intensity of physical exercise and are good markers of adaptation to physical exercise. The observed correlation between NAG/Cr and $\beta-2 \mathrm{M} / \mathrm{Cr}$ in both groups of the cadets may serve as a base of both types of physical exercise and proteinuria. The positive 
correlation between $\mathrm{TP} / \mathrm{Cr}$ and $\beta-2 \mathrm{M} / \mathrm{Cr}$ in group $\mathrm{A}$ after completing the training program (training III) may serve to assess the renal load. Comparison of both groups in relation to the general physical fitness and proteinuria indicates that the lower proteinuria, the better physical fitness.

\section{CONCLUSIONS}

Assayed urine proteins depend on the intensity of physical exercise, the type of exercise, and the degree of physical fitness.

\section{REFERENCES}

1. Kobos Z, Truszczyński O, Jedrys R, Terelak J. [Formation of sight-motor coordination by training on Special Aerial Gymnastics Instruments]. Med Lotn. 1994;122/125(1-4):12-5. Polish.

2. Ghieda MY, Samir SM, Ahmed NA. Effect of sport exercises on kidney. World J Sport Sci. 2011;2:107-11.

3. Poortmans JR. Postexercise proteinuria in humans. Facts and mechanisms. JAMA. 1985;253(2):236-40, http://dx.doi. org/10.1001/jama.1985.03350260088032.

4. Bakońska-Pacoń E, Borkowski J. The effect of the physical exercise on the activity of brush border enzymes and lysosomal enzymes of nephron excreted in the urine. Biol Sport. 2003;20(1):69-78.

5. Poortmans JR, Labilloy D. The influence of work intensity on post-exercise proteinuria. Eur J Appl Physiol. 1988;57(2): 260-3, http://dx.doi.org/10.1007/BF00640673.

6. Poortmans JR. Exercise and renal function. Sport Med. 1984;1:125-30, http://dx.doi.org/10.2165/00007256198401020-00003.

7. Poortmans JR, Engels MF, Sellier M, Leclercq R. Urine protein excretion and swimming events. Med Sci Sports Exerc. 1991;23(7):831-5, http://dx.doi.org/10.1249/00005768199107000-00010.

8. Noddeland H, Myhre K, Baldin UI, Andersen HAT. Proteinuria in fighter pilots after high $+\mathrm{Gz}$ exposure. Aviat Space Environ Med. 1986;57:122-5.
9. Sobiech KA, Bakońska-Pacoń E, Borkowki J. [Biochemical indices in sportment urine after different training strain]. Leistungssport. 1991;2:31-8. German.

10. Poortmans JR, Jealonz RW. Quantitative immunological determination of twelve plasma proteins excreted in human collected before and after exercise. J Clin Invest. 1968;47: 386-93, http://dx.doi.org/10.1172/JCI105735.

11. Tucker SM, Price RJ, Price RG. Characterization of human N-acetyl-beta-D-glukosaminidase isoenzymes as indicator of tissue damage in disease. Clin Chim Acta. 1980;102: 29-40, http://dx.doi.org/10.1016/0009-8981(80)90430-1.

12. Price RJ, Price RG, Fowler I. N-acetyl-beta-D-glukosaminidase in marmoset kidney: Serum and urine. Biochem J. 1978;175:859-60.

13. Yaguchi H, Ishigooka M, Hayami S, Kobayashi T, Kubota Y, Nakada TM, et al. The effect of triathlon on urinary excretion of enzymes and proteins. Int Urol Nephrol. 1998;30(2): 107-12, http://dx.doi.org/10.1007/BF02550562.

14. Harriss DJ, Atkinson G. Update - Ethical standards in sport and exercise science research. Int $\mathrm{J}$ Sports Med. 2011;32(11):819-21, http://dx.doi.org/10.1055/s-00311287829.

15. Maruhn D. Rapid colorimetric assay of $\beta$-galactosidase and N-acetyl- $\beta$-D glucosaminidase in human urine. Clin Chim Acta. 1976;73(3):453-61, http://dx.doi.org/10. 1016/0009-8981(76)90147-9.

16. Wochyński Z, Stelęgowski A, Kłossowski M. [Use of aerosynthetic efficiency test in selection of candidates to the Air Force Academy for Multirole Fighters F-16]. Pol Przegl Med Lotn. 2010;16(4):309-20. Polish.

17. Kokot F, Hyla-Klekot L. [Glomerular proteinuria: Selected pathophysiological aspects yesterday and today]. Nefrol Dial Pol. 2009;13:153-6. Polish.

18. Edes TE, Shah JH, Jayendra H, Thornton WHJR. Spontaneous decline in exercise-induced proteinuria during a 100-mile triathlon. South Med J. 1990;9:1044-6.

19. Montelpare WJ, Klentrou P, Thoden J. Continuous versus intermittent exercise effect of excretion of albumin and 
total protein. J Sci Med Sport. 2002;5(3):219-28, http:// dx.doi.org/10.1016/S1440-2440(02)80006-8.

20. Miyatake N, Shikata K, Makino H, Numata T. Comparison of muscle strength between subjects with and without proteinuria. Health. 2011;3(11):698-702, http://dx.doi.org/ 10.4236/health.2011.311117.

21. Bakońska-Pacoń E, Milnerowicz H, Borkowski J, Sobiech K. [Post-exercise changes in metalothioneine and $\mathrm{N}$-acetyl$\beta$-D-glucosaminidase in the light athletics urine]. Diagn Lab. 1996;312:157-62. Polish.

22. Borkowski J, Sobiech KA. Protein:creatinine and trypsin:protein ratios inhibitor in the urine of marathon runners. Eur J Appl Physiol. 1991;61(1-2):124-7, http://dx.doi. org/10.1007/BF00236705.

23. Sós C. Reduction of plasma lactate elevation and proteinuria by a complex dietary supplement in swimmer during overloading training. Acta Physiol Hung. 2004;91(3-4):211-9, http://dx.doi.org/10.1556/APhysiol.91.2004.3-4.5.

24. Bellinghieri G, Savica V, Santoro D. Renal alterations during exercise. J Ren Nutr. 2008;18(1):158-64, http://dx.doi. org/10.1053/j.jrn.2007.10.031.

25. Carlier B, Ninane G, Joris G. Specificity of urinary N-acetyl- $\beta$-D-glucosaminidase test in renovascular hypertension. Lancet. 1979;313:264-5, http://dx.doi.org/10.1016/ S0140-6736(79)90784-0.

26. Nowacka I, Sobiech KA, Kosendiak J. [Urine N-acety- $\beta$-Dglucosaminidase in the light athletics during training cycle]. Research problems in light athletics. Proceedings of the Conference in University School of Physical Education; 1994 Nov 18-19; Wrocław, Poland. Wrocław: University School of Physical Education; 1995. p. 129-136. Polish.

27. Myai T, Ogata M. Changes in the concentrations of urinary proteins after physical exercise. Acta Med Okayama. 1990;5:263-6.
28. Haraldsson B, Jeansson M. Glomerular filtration barrier. Curr Opin Nephrol Hypertens. 2009;18(4):331-5, http:// dx.doi.org/10.1097/MNH.0b013e32832c9dba.

29. Haraldsson B, Nyström J, Deen WM. Properties of the glomerular barier and mechanism of proteinuria. Physiol Rev. 2008;88(2):451-87, http://dx.doi.org/10.1152/physrev. 00055.2006.

30. Salmon AH, Neal CR, Harper SJ. New aspects of glomerular filtration barrier structure and function: Five layers (at least) not three. Curr Opin Nephrol Hypertens. 2009;18(3):197205, http://dx.doi.org/10.1097/MNH.0b013e328329f837.

31. Singh A, Satchell SC, Neal CR, McKenzie EA, Tooke JE. Glomerular endothelial glycocalix constitutes a barrier to protein permeability. J Am Soc Nephrol. 2007;18(11): 2885-93, http://dx.doi.org/10.1681/ASN.2007010119.

32. Sentürk UK, Kuru O, Kocer G. Biphasic pattern of exercise-induced proteinuria in sedentarny and trained men. Nephron Physiol. 2007;105(2):22-32, http://dx.doi. org $/ 10.1159 / 000097953$.

33. Ohno H, Yamashita H, Ookawara T, Kizaki T, Sato Y, Taniguchi N. Effect of physical exercise on urinary excretion of $\mathrm{ZnCu}$-superoxide dismutase in male high school students. Acta Physiol Scand. 1993;148:353-5, http://dx.doi. org/10.1111/j.1748-1716.1993.tb09567.x.

34. Bovio G, Piazza V, Ronchi A, Montagna G, Semerano L. Zinc deficiency and low testosterone are associated with proteinuria. J Alzheimers Dis. 2010;19:481-8.

35. Houser MT, Jahn MF, Kobayashi A, Walburn J. Assessment of urinary protein excretion in the adolescent: Effect of body position and exercise. J Pediatr. 1986;109(3):556-61, http:// dx.doi.org/10.1016/S0022-3476(86)80143-3.

36. Wochyński Z, Jędrys R, Stelęgowski A. Methodology of training on special aviation gymnastic instruments. Dęblin: Polish Air Force Academy; 2010. p. 43-59.

This work is available in Open Access model and licensed under a Creative Commons Attribution-NonCommercial 3.0 Poland License - http://creativecommons.org/ licenses/by-nc/3.0/pl/deed.en. 